\title{
CAMA
}

Centre for Applied Macroeconomic Analysis

\section{Asian Fragmentation in the Global Financial Crisis}

\section{CAMA Working Paper 30/2014 March 2014}

Toshihiro Okubo

Keio University and

Centre for Applied Macroeconomic Analysis, ANU

\section{Fukunari Kimura}

Keio University and

ERIA

\section{Nozomu Teshima}

House of Councillors

The National Diet of Japan

\section{Abstract}

This paper studies the impact of the Global Financial Crisis of 2008 on Japanese exports, focusing on international production networks in machinery sectors. For our survival analysis, we estimate a Cox proportional hazards model. Consequently, we find that Japanese exports to Asian countries, parts and components trade in particular, were less likely to stop during the crisis. Even if they stopped, such trade is more likely to be revived. Therefore, regardless of the worldwide economic crisis, Japan maintained trade relationships in parts and components in the machinery sectors. 


\section{Keywords}

Financial crisis, Asian trade, parts and components, exit-entry diagram, survival analysis

\section{JEL Classification}

F14, F61

Address for correspondence:

(E) cama.admin@anu.edu.au

The Centre for Applied Macroeconomic Analysis in the Crawford School of Public Policy has been established to build strong links between professional macroeconomists. It provides a forum for quality macroeconomic research and discussion of policy issues between academia, government and the private sector.

The Crawford School of Public Policy is the Australian National University's public policy school, serving and influencing Australia, Asia and the Pacific through advanced policy research, graduate and executive education, and policy impact. 


\title{
Asian Fragmentation in the Global Financial Crisis
}

\author{
Toshihiro Okubo \\ Keio University and CAMA, Australian National University \\ Fukunari Kimura \\ Keio University and ERIA \\ and \\ Nozomu Teshima \\ House of Councillors \\ The National Diet of Japan
}

December 2013

\begin{abstract}
This paper studies the impact of the Global Financial Crisis of 2008 on Japanese exports, focusing on international production networks in machinery sectors. For our survival analysis, we estimate a Cox proportional hazards model. Consequently, we find that Japanese exports to Asian countries, parts and components trade in particular, were less likely to stop during the crisis. Even if they stopped, such trade is more likely to be revived. Therefore, regardless of the worldwide economic crisis, Japan maintained trade relationships in parts and components in the machinery sectors.
\end{abstract}

Keywords: Financial crisis, Asian trade, parts and components, exit-entry diagram, survival analysis

JEL Classification: F14, F61

Correspondence: Toshihiro Okubo, Faculty of Economics Keio University and CAMA, Crawford School of Public Policy, Australian National University . 2-15-45 Mita, Minato-ku, Tokyo,108-8345 Japan mail: okubo@econ.keio.ac.jp +81-3-5418-6589 Fukunari Kimura, Faculty of Economics. 2-15-45 Mita, Minatoku, Tokyo, 108-8345, Japan mail:fkimura@econ.keio.ac.jp

Acknowledgements: We thank two anonymous referees, Ayako Obashi and Yuta Watabe for many helpful suggestions. This research was partly financed by Grant-in-Aid for Scientific Research (Grant number 25780169). 


\section{Introduction}

The financial crisis of 2008 has seriously damaged the world economy. On September $29^{\text {th }}$, 2008, the New York stock market collapsed following the bursting of the US housing market bubble in 2007. The financial crisis quickly spread around the world, with many economists claiming it to be the worst economic crisis since the Great Depression of $1929 .{ }^{1}$ The crisis collapsed financial sectors, drastically depressed stock markets and caused a decline in international trade for many countries (Baldwin and Evenett, 2009). According to Levchenko et al. (2010), the reduction in trade is far larger than in previous recessions in the United States. Furthermore, the country worst hit by the crisis was Japan. As shown in Tanaka (2009), the sudden contraction of Japanese exports was amplified by the international production networks that Japanese multinationals established in Asian countries.

This paper sheds light on how seriously the Global Financial Crisis of 2008 affected Japanese international trade and how machinery production networks were sustained during the crisis. In particular, this paper uses Japanese trade (export) data for the machinery sector at a detailed product level and investigates how the financial crisis reduced exports. This is done using survival analysis. Our results suggest that Asia's good trade performance is likely to be maintained and will survive the Global Financial Crisis.

One reason for using Japanese trade data is data availability. Japan has detailed product-level (nine-digit) monthly trade statistics. Another reason is that Japan is a key player in Asian fragmentation. In particular, the machinery sector, a major export sector, has expanded its production networks and fragmented production processes across Asia, significantly increasing Japanese, as well as Asian, trade. Thus, this is a good case study for testing the robustness (or resilience) of international production networks during the Global Financial Crisis.

This paper is related to two strands of the trade literature. One is the impact of the crisis on trade, and the other is production networks in Asia, so-called Asian fragmentation. In the first strand, which recently emerged and expanded, some papers have investigated the Global Financial Crisis of 2008. Levchenko et al. (2011), Ahn et al. (2011), Bems et al. (2011) and Amiti and Weinstein (2011) study the role of the crisis in the decline of world trade. A main

\footnotetext{
${ }^{1}$ For example, Paul Krugman called it “a Second Great Depression” (The New York Times, January $4^{\text {th }}, 2009$ ). Crowley and Luo (2011) called the drastic reduction in world trade "the Great Trade Collapse of 2008-2009".
} 
feature of these previous studies is to highlight how fragile international trade was in the US and Europe. However, they do not investigate East Asian trade or do not attempt to test the robustness of production networks, such as Asian fragmentation, against financial shocks. In the second strand, there are some previous studies on Asian fragmentation. Although production networks and fragmentation have been conceptually proposed for a long time (e.g. Jones and Kierzkowski, 1990; Deardorff, 2001), empirical studies are relatively new (Ando and Kimura, 2005; Kierzkowski and Lurong, 2005; Athukorala and Yamashita, 2006; Jones, Fukao and Okubo, 2012). Their main finding is that contemporary Asian trade is primarily intermediate goods trade; in particular, parts and components trade in the machinery sector. The main focus of these previous studies is trade patterns through fragmentation and the characteristics of Asian fragmentation. They do not investigate the impact of economic crises nor discuss the degree of robustness of Asian fragmentation. ${ }^{2}$

This paper integrates these two strands to fill the gaps. To shed light on the transitional impact of the crisis, this paper adopts survival analysis. It is to be expected that an economic crisis will permanently stop some exports, and that more and more products will cease to be exported as the crisis deepens. Some products will continue to export. Furthermore, as the economy recovers from the crisis, some export products will be revived, and so trade should recover as time goes by. Our main question is whether trade related to Asian fragmentation exporters either stopped (so-called exit) or continued (so-called survival) during the financial crisis, and whether those that did exit later re-entered the export market (so-called re-entry). As trade related to fragmentation tends to be relation-specific and involve differentiated intermediate products, we can hypothesise that trade related to Asian fragmentation is more likely to have survived the Global Financial Crisis than trade in other products traded with other regions.

\subsection{Survival Analysis and International Trade}

Survival analysis, which is our estimation methodology, is a relatively new technique in the international trade literature. Besedes and Prusa (2006a) is the first study to apply survival analysis to international trade. Besedes and Prusa (2006b) classifies trade products as either differentiated products or homogeneous products and concludes that differentiated goods are more likely to survive and homogeneous goods are more likely to exit the export market.

\footnotetext{
${ }^{2}$ The exceptions are Obashi (2011) and Ando and Kimura (2012). However, as explained below, this paper employs a more detailed analysis with careful data handling and improved methodology.
} 
Furthermore, Besedes (2008) finds that trade products with high entry costs are more likely to survive.

Similar to our paper, Obashi $(2010,2011)$ is the first to employ survival analysis to study machinery trade in production networks across Asia. Using the Harmonised Commodity Description and Coding System (HS) six-digit annual trade data from Asian countries, Obashi (2010) estimates a Cox proportional hazards model and presents Kaplan-Meier estimates, while Obashi (2011), using the same methodology, investigates the impact of the Asian Currency Crisis in 1997-1998 and finds that parts and components trade in Asia recovered rapidly after the crisis.

Ando and Kimura (2012) conduct a quick study just after the East Japan Earthquake and compare the impact of the Global Financial Crisis and the East Japan Earthquake on the Japanese Exports. A major focus of the paper is the decomposition of intensive and extensive margins at the drop and the recovery of exports facing the two different shocks and concludes that the Global Financial Crisis had much larger and prolonged impacts than the East Japan Earthquake. With using the HS nine-digit export data for selected months, the robustness of parts and components trade is also confirmed with the both shocks. Ando and Kimura (2012) include only a simple non-parametric estimation of the survival function, the Kaplan-Meier estimates.

Our paper is in line with Obashi (2011) and Ando and Kimura (2012) but focuses on the impact of the Global Financial Crisis on Japanese machinery exports by applying more rigorous survival analysis with more careful data handling. First, we employ the HS ninedigit monthly export data of Japan. The detailed commodity classification is needed for capturing the nature of exit and re-entry. High-frequency data are also desirable for analysing the impact of macro shocks with carefully observing the exit and recovery. Second, to highlight patterns of exit and re-entry at the country-product level, our paper proposes a novel diagram that we call the "exit-re-entry diagram". This is a powerful tool to visualize the tendency of the exit and re-entry pairs, particularly useful for the comparison across commodity groups as well as trading partners. It is also useful to casually check possible outliers. Third, our estimations employ some important explanatory variables that are missing in Obashi (2010, 2011) and Ando and Kimura (2012). The "age" of country-products and product quality, proxied by per-unit price, are crucial factors in our survival analysis. The age of a product is measured as the number of consecutive months during which transactions occur. In particular, we will find that the age matters a lot for survival. This suggests that the 
introduction of the age variable is essential to a rigorous survival analysis with ofteninterrupted monthly data. Fourth, to rule out model misspecification, a diagnostic test is done, because the Cox proportional hazards model involves several assumptions.

The next section presents a summary of the data on Japanese trade during the Global Financial Crisis. Section 3 presents an exit-re-entry diagram, while Section 4 describes the empirical strategy and Section 5 reports the results. Sections 6 and 7 present the interpretation of our results and concluding remarks, respectively.

\section{Data Description}

We use Japan's customs trade data, Trade Statistics of Japan, compiled by the Ministry of Finance (MOF). The data are monthly disaggregated product-level data by destination (i.e. country-product) recorded at free on board (FOB) value. The products are classified at the nine-digit level. ${ }^{3}$ Using the export data, we construct binary data for each country-product, in which a zero value means no exports and unity means exports occurred. Then the binary data sets are panelled at the nine-digit product level for each destination. The definition of machinery products and parts and components follows Ando and Kimura (2005). ${ }^{4}$ Asia in our paper follows the definition of MOF. ${ }^{5}$ Our survival analysis mainly uses monthly trade data during the financial crisis, i.e. from October 2008 to October 2009.

Next, we define the terminology used in this paper: crisis period, exit, re-entry and new-entry as shown in Table 1. First, the crisis period is defined. Figure 1 shows the trend in Japan's

\footnotetext{
${ }^{3}$ The first six digits of the nine-digit code are based on the international HS code, while the last three digits are country-specific, prepared by MOF.

${ }^{4}$ Machinery goods are composed of general machinery, electric machinery, transport equipment, and precision machinery (HS 84-92) in our paper. The definition of machinery parts and components follows Ando and Kimura (2005), adjusted by the 2007 version of HS classification: 8406, 8407, 8408, 8409, 8410, 8411, 8412, $8413,8414,8416,8417,8431,8448,8466,8473,8480,8481,8482,8483,8484,8486,8487,8503,8505,8507$, 8511. 8512, 8522, 8529, 8531, 8532, 8533, 8534, 8535, 8536, 8537, 8538, 8539, 8540, 8541, 8542, 8544, 8545, $8546,8547,8548,8607,8706,8707,8708,8714,8803,8805,9001,9002,9003,9013,9014,9033,9104,9110$, $9111,9112,9113,9114,9209,840140,840290,840390,840490,841520,841590,841891,841899,841990$, $842091,842099,842123,842129,842131,842191,842199,842290,842390,842490,843290,843390$, 843490, 843590, 843691, 843699, 843790, 843890, 843991, 843999, 844090,844190, 844240, 844250, 844391, $844399,845090,845190,845240,845290,845390,845490,845590,846791,846792,846799,846890$, $847490,847590,847690,847790,847890,847990,850490,850690,850870,850990,851090,851390$, 851490, 851590. 851690. 851770, 851840, 851850, 851890, 852352, 853090, 854390, 870990, 871690, 900590, 900691, 900699, 900791, 900792, 900890, 901090, 901190, 901290, 901590. 901790, 902490, 902590, 902690, 902790, 902890, 902990, 903090, 903190, 903290. Machinery final products are defined as all machinery products other than parts and components.

${ }^{5}$ Asia is defined as South Korea, North Korea, China, Taiwan, Mongolia, Hong Kong, Vietnam, Thailand, Singapore, Malaysia, Brunei, Philippines, Indonesia, Cambodia, Laos, Myanmar, India, Pakistan, Sri Lanka, Maldives, Bangladesh, Macao, Afghanistan, Nepal, and Bhutan.
} 
export values. The bubble burst in the US housing market in 2007, which then led to the US stock market collapse and recession in the global economy. The shock spread all over the world. Japan experienced a large decline in trade of 40 per cent following the outbreak of the financial crisis in September 2008. January 2009 marks the bottom of the decline in Japan's exports. Afterward, trade largely recovers and reaches a plateau in January 2010, albeit at a lower level than pre-crisis. Thus, this paper defines the crisis period as from October 2008 to October 2009. Based on this crisis period, "exit" from the export market is defined as no exports after October 2008 for those exports that continued until at least September 2008. As shown in Table 1, for exports continuing every month from " $t 0$ " to the month of exit, we can define the number of consecutive months until exit as the trade duration, or, in short, the age of the country-product. ${ }^{6}$ This indicates how long the trade relationship lasts. Then "re-entry" occurs when the country-product exits after October 2008 and then re-starts exporting before October 2009. Finally, "new entry" is defined as a country-product that does not export as of September 2008 and commences exports during October 2008 to September 2009. The main focus of our paper is on exit and re-entry of country-products during the crisis period. New entry is discussed in the Appendix.

Before going into our analyses, we provide a brief overview of Japan's machinery sector exports. The machinery sector accounts for more than 70 per cent of Japan's exports (Figure 1). Figure 2 graphs the number of country-products, i.e. exported products by destination, from 2007 to 2010 . This is the so-called extensive margin. ${ }^{7}$ The number falls due to the crisis and then recovers somewhat after the crisis. ${ }^{8}$ Compared with Figure 1, the fluctuation is small. The stable number of transactions over time indicates that once trade starts, trade relationships last for a long time. However, the Global Financial Crisis seems to have damaged many of these relationships, highlighting how seriously the crisis damaged trade.

\footnotetext{
${ }^{6}$ We note that "t0" differs by country-product. Because of the data qualification, the earliest period for t0 is April 1988.

7 There are various definitions of extensive margin. Our definition is in line with Hummels and Klenow (2005). The impact of the crisis on the intensive margin is studied by Bricongne et al. (2012) using French firm data. ${ }^{8}$ Teshima (2012) presents a decomposition analysis of Japan's trade at the nine-digit product level and finds that more than 40 per cent of the decline in exports can be explained by the fall in export quantities.
} 


\section{Stylised Facts for Machinery Trade}

\section{1. $\quad$ Exit and Re-entry Probabilities}

This section overviews exit and re-entry in the machinery sector. In general, recessions lead to a collapse in trade relationships and thus increase the number of exits. Table 2 presents an overview of the number of exits and surviving products by destination (country-product) in the machinery sector. As the upper panel of Table 2 shows, the number of country-products for final products and parts and components (henceforth, $\mathrm{P} \& \mathrm{C}$ ) in the machinery sector are almost the same. However, as shown in the bottom panel, around 30 per cent of machinery trade is within Asia. Machinery trade in final products and P\&C is active across Asian countries because of the production networks. Table 3 shows the probability of exit and reentry. ${ }^{9}$ Final products and P\&C are in sharp contrast. As shown in the upper panel of Table 3 , $\mathrm{P} \& \mathrm{C}$ have a smaller probability of exit (0.393) and larger probability of re-entry (0.65) than final products ( 0.572 for exit and 0.597 for re-entry). Turning to the dimensions of the destinations (the middle panel of Table 3 ), Asia sees a lower probability of exit (0.361) and a high probability of re-entry (0.69) than all other regions, except North America. Furthermore, as shown in the bottom panel of Table 3, P\&C in Asia have a very small probability of exit $(0.257)$ and final products also have a small probability of exit $(0.475)$.

Table 3 reports the probability by age, defined as the time period of trade before exit. Interestingly, as shown in all panels of the table, almost all machinery products with less than half a year of transactions exit in all categories ( 0.9 to 1 ). As the transaction period lengthens, the probability of exit lowers. Products with more than three years have a $0.1-0.2$ chance of exit. In particular, the probability of exit in Asian P\&C is 0.065 . Turning to re-entry, as the transaction period increases, the probability of re-entry also increases in products with less than three years. For most country-products with more than three years, the probability of reentry is around $0.8-0.9$.

In summary, the crisis reduced the value of, as well as the number of country-products in, Japan's exports. However, exit is less likely to occur in Asian trade.

\footnotetext{
${ }^{9}$ The probability of exit is defined as the share of exit country-products in the total number of country-products. The probability of re-entry is defined as the share of re-entry country-products in the total number of exit country-products.
} 


\subsection{Exit-Re-entry Diagram for Machinery Products}

Next, we discuss exit and re-entry in the machinery products industry in more detail. The issue here is whether all country-products that exited during the crisis re-start or not. Figure 3 presents an exit-re-entry diagram. All machinery products are plotted in Figure 3-1. Each point represents a nine-digit machinery product. The axes measure the number of export destinations of exit and re-entry for each product in the period from October 2008 to October 2009. The horizontal axis measures exit and the vertical axis measures re-entry. Note that it only contains products that are traded as of September 2008, and thus new-entry products are excluded. New entry in the Japanese case is small enough to ignore (see Appendix for more details).

Points on the 45-degree line indicate that the number of export destinations is the same preand post-crisis, meaning that even if the products temporarily exit, they re-enter. Points below the 45-degree line indicate the products are less likely to re-enter after exit. It is apparent that the points are closer to the 45-degree line when the number of destinations is low and tend to be further below 45-degree line as the number of destinations increases. Thus, products with a small number of destinations before the crisis are more likely to be revived. On the other hand, products with a larger number of destinations before the crisis have seen a greater reduction in the number of destinations after the crisis. Products are further below the 45degree line as the number of destinations increases.

Using this exit-re-entry diagram, several additional features are apparent. In Figure 3-2, which is coloured by sectors, some general machinery products are far below the 45-degree line, while some automobile products are closer to the 45-degree line. Otherwise, there seems to be no clear relationship in terms of sectoral characteristics. Second, product characteristics, i.e. final products or $\mathrm{P} \& \mathrm{C}$, are coloured in Figure 3-3. P\&C are closer to the 45-degree line and slightly above final goods. This indicates that $\mathrm{P} \& \mathrm{C}$ trade is more likely to be revived after exit than trade in final products.

Finally, we disaggregate each product by age. Figure 3-4 is coloured by age. Each product is disaggregated into one of five groups depending on the trade duration before exit. We can clearly see that products with longer transaction periods are located closer to the 45-degree line, whereas products with shorter transaction periods are located further below the 45degree line. This indicates that products with longer transaction periods are more likely to reenter, but products with shorter transaction periods find it difficult to re-enter once they exit. 


\section{Estimation Strategy}

To formalise our discussion above, using the above-mentioned country-product data, we now conduct survival analysis for Japan's exports in machinery products.

\subsection{Non-parametric Estimates: Kaplan-Meier Estimates}

First, we consider a simple non-parametric estimate of the survivor function. The KaplanMeier estimates of the survivor function, $\mathrm{S}(\mathrm{t})$, are given as

$$
\hat{S}(t)=\prod_{t_{j}<t} \frac{n_{j}-d_{j}}{n_{j}}
$$

where $n_{j}$ is the number of country-products that have survived to $t_{j}$ months and $d_{j}$ is the number of country-products that die at $t_{j}$.

First, Figure 4 describes the exit case. Survival rates are the highest for Asian P\&C for all time periods, with Asian trade or $\mathrm{P} \& \mathrm{C}$ trade are the second highest, and the others are the lowest for all time periods. These gaps are widening slowly over time. Asian $\mathrm{P} \& \mathrm{C}$ trade is substantially higher than all other categories.

Figure 5 reports the estimated Kaplan-Meier failure rates for re-entry. The estimated failure curves are upward sloping with steeper slopes for Asian $\mathrm{P} \& \mathrm{C}$ and final products. This indicates that revival rates are always higher for Asian $\mathrm{P} \& \mathrm{C}$ and final products for all time periods. Slightly different from the exit case, all Asian trade has higher revival rates.

\subsection{Cox Proportional Hazards Model}

Next, we estimate the semi-parametric Cox proportional hazards model. The impact of the financial crisis on exit and re-entry is estimated, controlling for country-product-specific variables. Generally, when an incident (exit or re-entry) occurs at (discrete) time $T=t_{j}$ $(\mathrm{j}=1,2,3 \ldots \mathrm{n})$ with probability density function $p\left(t_{j}\right)=\operatorname{Pr}\left(T=t_{j}\right)$, the survivor function is defined as

$$
\mathrm{S}(\mathrm{t})=\operatorname{Pr}(\mathrm{T}>t)=\sum_{t_{j}>t} p\left(t_{j}\right)
$$

The hazard function is given as

$$
\mathrm{h}\left(\mathrm{t}_{j}\right)=\operatorname{Pr}\left(T=t_{j} \mid T \geq t_{j}\right)=\frac{p\left(t_{j}\right)}{S\left(t_{j-1}\right)} .
$$

Then the hazard and survival functions have the following relationship 


$$
\mathrm{S}\left(\mathrm{t}_{j}\right)=\prod_{t_{j}<t}\left(1-\mathrm{h}\left(\mathrm{t}_{j}\right)\right) .
$$

The hazard rate for country-product $i$ is given by

$$
\mathrm{h}\left(t \mid X_{i}\right)=h_{0}(t) \exp \left(X_{i} \beta\right),
$$

where $X$ denotes i's covariate of country-product-specific variables and its estimated coefficient $\beta$. The baseline hazard rate is given as $h_{0}(t)$. The hazard rate corresponds to the baseline hazard if all covariates are zero. The exponential part can be defined as the hazard ratio for a marginal change of the covariate. The hazard ratio is greater than one and more likely to cause the event if the coefficient is negative, i.e. negatively affects the duration of trade relationships, and vice versa. A ratio equal to one means no impact on the duration of trade relationships.

The country-product-specific variables, $X$, are GDP of destination, geographical distance, per-unit price, age, and dummies ( $\mathrm{P} \& \mathrm{C}$, Asia and Asian $\mathrm{P} \& \mathrm{C}$ dummies).${ }^{10}$ Age denotes the trade duration before the exit and is defined as the number of consecutive months of trade before exit. The unit price of each product is used as a proxy for the quality of the product, where higher quality products have a higher per-unit price, as is often discussed in the trade and quality literature. Thus, we expect that destinations with higher ages (longer relationships) are more likely to keep trading. High quality products are generally better able to survive transportation to far-off destinations. This is well-known as the Alchian and Allen effect (Alchian and Allen,1964; Hummels and Skiba, 2004).

\section{Estimation Results}

\section{1. $\quad$ Exit}

Table 4 reports estimation results for exit. As shown in columns (1) and (2), GDP is significantly negative, and distance is significantly positive. Exports to larger markets are less likely to exit. Even if the crisis is serious, a larger economy is more likely to keep transacting because of greater demand. Destinations closer to Japan are more likely to keep transacting. Geographical proximity makes it easier to enforce contracts because of less information asymmetry. Then coefficients on age are significantly negative, and thus we expect that longer trade relationships are more likely to be sustained. Importantly, the Asia and P\&C

\footnotetext{
${ }^{10}$ See Appendix Tables 1 and 2 for basic statistics and a correlation matrix of all variables. GDP and distance data are taken from CEPII (http://www.cepii.fr/anglaisgraph/bdd/distances.htm). All of these variables are in logarithms. As discussed in Section 2, the definition of Asia is from MOF and the definition of P\&C follows Ando and Kimura (2005).
} 
dummies are both significantly negative in all of the regressions. This means that Asian trade and $\mathrm{P} \& \mathrm{C}$ trade, by reducing hazard rates, are less likely to exit.

To highlight the unit-price impact, we split the sample into $\mathrm{P} \& \mathrm{C}$ and final products. Columns (3) and (4) report the results. Interestingly, the signs of unit prices are opposite. In the P\&C estimation, column (3), the coefficient is significantly positive. This may be due to the fact that unit prices of $\mathrm{P} \& \mathrm{C}$ are poor indicators of the quality. Actually, unit prices of $\mathrm{P} \& \mathrm{C}$ may reflect the degree of processing, rather than differences between high-end and low-end. ${ }^{11} \mathrm{By}$ contrast, for final products, column (4), the coefficient is significantly negative. While high quality final products are less likely to exit, low quality ones are more likely to exit. This indicates that final products seem to go along with the usual Alchian-Allen story.

\subsection{Re-entry}

Next, Table 5 reports results for re-entry. The sample used for the four regressions limits the country-products to those that exited after October 2008, so as to investigate whether the country-product resumes trading or remains non-trading. Thus, the signs should be opposite to those in the case of exit. As shown in columns (1) and (2), GDP is significantly positive, and distance is negative. Age is significantly positive. Exports to larger markets are more likely to re-start, and destinations closer to Japan are more likely to revive the trade relationship. Even if the crisis is serious, a larger economy and closer market associated with long transaction experience is more likely to recover the trade relationship. Importantly, the Asian and $\mathrm{P} \& \mathrm{C}$ dummies, which are our central issue, are all positively significant. This indicates that Asian trade, and in particular Asian P\&C trade, is more likely to be revived if the product exits the export market. Unit prices in columns (1) and (2) are insignificant. To investigate unit prices further, we split the sample into $\mathrm{P} \& \mathrm{C}$ and final products. Columns (3) and (4) report the results. Unit price is significantly negative for $\mathrm{P} \& \mathrm{C}$, although significantly positive for final products. Low-price $\mathrm{P} \& \mathrm{C}$ are more likely to re-enter the market, while highprice final products are more likely to re-enter the market. These results are consistent with the exit case.

From all these outcomes, we conclude that Asian and P\&C trade are less likely to exit and more likely to re-enter the export market. This indicates that Asian machinery trade is based on long-run relationships and Asian fragmentation is fairly robust against crises.

\footnotetext{
${ }^{11}$ Ando (2006) actually finds that unit export prices of $P \& C$ tend to be lower than unit import prices of $P \& C$ for Japan while the opposite for Indonesia. This suggests that unit prices of $\mathrm{P} \& \mathrm{C}$ are poor indicators of the quality.
} 


\subsection{Goodness-of-fit test}

Finally, Cox-Snell residuals are employed to assess overall model fit. When the model fits the data, the plot of the cumulative hazard rates and residuals should be a straight line along the diagonal line. As a result, the plots in all estimations in the exit and re-entry cases are both straight lines along the 45-degree line, although the figures are omitted because of space limitations. These results indicate that our Cox proportional hazards model fits the data well.

\section{Asian Fragmentation and Parts and Components Trade}

Our main results are consistent with previous studies on Asian fragmentation, in particular Obashi (2011) and Ando and Kimura (2012). Asian trade and in particular Asian P\&C trade are robust, in which the trade relationship is sustainable even during a crisis or recovers faster than all other products. This is mainly driven by Asian fragmentation.

Asian P\&C trade relationships can be interpreted using several hypotheses. First, business partnerships in production networks are not easily replaced (Rauch and Watson, 2004; Antras, 2003). This might encourage more long-term trade relationships. In Asia, it might be relatively difficult to find business partnerships across developing countries because of the huge diversity of customs, cultures and languages. However, once partnerships are formed, it might be easier to sustain the relationship than to find new ones. More generally, relationspecific transactions might also be important. High sunk costs for building production networks across countries make them costly to cancel. A second possible interpretation relates to learning by exporting and lock-in. Once a certain product is exported to a specific destination, the exports are sustained by accumulating know-how through learning by doing. Stated differently, trade is locked-in and the duration of the trade relationship is likely to be longer. Thus, this is more likely to lock-in trade relationships and prolong trade duration. Finally, production networks in machinery industries consist of quick, high frequency and synchronized transactions. The networks in Asian machinery sectors are as sophisticated and complicated. The interruption of a part supply may stop the whole production network, generating strong incentives for private companies to maintain/resume the system quickly.

\section{Conclusions}

This paper investigated the robustness of Asian fragmentation during the Global Financial Crisis of 2008 to 2009, using survival analysis on Japanese product-level export data. We found that Asian trade, in particular Asian P\&C trade, is less likely to exit from the export 
market. Even if it exits, the trade relationship is more likely to be revived. Regardless of the Global Financial Crisis, Asian P\&C trade can be sustained and maintain production networks across Asian countries. While a few current studies on trade during the financial crisis investigate the fragility of trade relationships, this paper examined the robustness of Asian fragmentation during the crisis. We have shown that Asian fragmentation successfully shares risk leading to robust trade relationships that might be a source of the dramatic economic growth in Asia.

This paper used trade data to investigate trade flows. Possible future research could be to investigate Asian fragmentation and the supply chain more rigorously, in which trade flows are linked to firm production using firm level data.

\section{References}

Ahn, J. B, M. Amiti, and D. E. Weinstein. (2011). "Trade Finance and the Great Trade Collapse," American Economic Review: Papers \& Proceedings, 101(3): 298-302.

Alchian, A. A., and W. R. Allen (1964). University Economics. Belmont, CA: Wadsworth

Amiti, M and D. E. Weinstein (2011). "Exports and Financial Shocks," Quarterly Journal of Economics, 126:1841-1877

Ando, M. (2006). "Fragmentation and Vertical Intra-industry Trade in East Asia”, North American Journal of Economics and Finance, 17:257-281.

Ando, M. and F. Kimura. (2005). "The formation of international production and distribution networks in East Asia. In International trade” NBER-East Asia seminar on economics. Vol. 14, edited by T. Ito and A. Rose. Chicago: The University of Chicago Press. First version, NBER Working Paper 10167.

Ando, M. and F. Kimura (2012) "How Did the Japanese Exports Respond to Two Crises in the International Production Networks? The Global Financial Crisis and the East Japan Earthquake." Asian Economic Journal, Vol. 26, No. 3: 261-287.

Antràs, P. (2003): "Firms, Contracts, and Trade Structure", Quarterly Journal of Economics, 118(4):13751418.

Athukorala, P and N. Yamashita, (2006). "Production fragmentation and trade integration: East Asia in a global context," The North American Journal of Economics and Finance, 17(3): 233-256.

Baldwin, R and S.J. Evenett (2009). The collapse of global trade, murky protectionism, and the crisis: Recommendations for the G20, E-book, VoxEU.org. 
Baldwin, R. (2006). "Globalisation: the great unbundling(s)", Chapter 1, in Globalisation challenges for Europe, Secretariat of the Economic Council, Finnish Prime Minister's Office, Helsinki, 2006, pp $5-47$.

www.graduateinstitute.ch/webdav/site/ctei/shared/CTEI/Baldwin/Publications/Chapters/Globaliza tion/Baldwin_06-09-20.pdf

Bems, R., Johnson, Robert C., and Yi, Kei-Mu. (2011). "Vertical Linkages and the Collapse of Global Trade," American Economic Review: Papers \& Proceedings, 101(3): 308-312.

Besedeš, T.(2008). "A Search Cost Perspective on Formation and Duration of Trade," Review of International Economics, 16(5): 835-849.

Besedeš, T. and T. J. Prusa. (2006a). "Ins, outs and the duration of trade," Canadian Journal of Economics, 39: $266-295$

Besedeš, T. and T. J. Prusa. (2006b). "Product differentiation and duration of US import trade," Journal of International Economics, 70: 339-358.

Bricongne, J-C, L. Fontagné, G.Gaulier, D.Taglioni, and V.Vicard (2012). "Firms and the global crisis: French exports in the turmoil," Journal of International Economics, 87(1):134-146.

Crowley, M. A. and X. Luo (2011). “Understanding the Great Trade Collapse of 2008-09," Economic Perspectives $352^{\text {nd }}$ Quarter, Federal Reserve Bank of Chicago.

Deardorff, A. V. (2001). "Fragmentation in Simple Trade Models," North American Journal of Economics and Finance 12: 121-137.

Fukao, K. and T. Okubo (2011). "Why Has the Border Effect in the Japanese Machinery Sectors Declined?: The Role of Business Networks in East Asian Machinery Trade," Journal of Economic Integration, 26: 651-671.

Hummels, D and P. J. Klenow, (2005). "The Variety and Quality of a Nation's Exports," American Economic Review, 95(3): 704-723.

Hummels, D. and A. Skiba (2004): "Shipping the Good Apples Out? An Empirical Confirmation of the Alchian-Allen Conjecture," Journal of Political Economy, 112(6): 1384-1402.

Haddad, M., A. Harrison, and C. Hausman. (2010). "Decomposing the Great Trade Collapse: Products, Prices, and Quantities in the 2008-2009 Crisis," NBER Working Paper 16253.

Jones, R. W. and H. Kierzkowski. (1990). "The Role of Service in Production and International Trade: A Theoretical Framework." In The Political Economy of International Trade: Essays in Honor of Robert E. Baldwin, edited by In R. W. Jones and A. O.Krueger. Oxford: Basil Blackwell.

Jones, R., H.Kierzkowski and C.Lurong, (2005). "What does evidence tell us about fragmentation and outsourcing?," International Review of Economics \& Finance, 14(3): 305-316. 
Kimura, F. and M. Ando (2005). "Two-dimensional fragmentation in East Asia: Conceptual framework and empirics," International Review of Economics \& Finance, 14(3): 317-348.

Levchenko, A, L. Lewis, and L.Tesar. (2010). "The Collapse of International Trade during the 2008-2009 Crisis: In Search of the Smoking Gun.” IMF Economic Review, 58(2): 214-53.

Levchenko, A. A., L. T. Lewis, and L. Tesar. (2011). "The Collapse in Quality Hypothesis," American Economic Review: Papers \& Proceedings, 101(3): 293-297.

Obashi, A. (2010). "Stability of Production Networks in East Asia: Duration and Survival of Trade," Japan and the World Economy 22(1): 21-30.

Obashi, A. (2011). "Resiliency of production networks in Asia: Evidence from the Asian crisis," Studies in Trade and Investment, in: Trade-led growth: A sound strategy for Asia, chapter 3 United Nations Economic and Social Commission for Asia and the Pacific (ESCAP).

Rauch, J. and J. Watson, (2004). "Network Intermediaries in International Trade," Journal of Economics and Management Strategy, 13(1): 69-93.

Tanaka, K. (2009) “Trade Collapse and International Supply Chains: Japanese Evidence”, in The Great Trade Collapse: Causes, Consequences and Prospects ed. Richard Baldwin, VoxEU.org, 2009

Teshima, N. (2012). "On the impact of the Great Financial Crisis on Japan's trade in machinery parts and components" (Sekai Kinyu Kiki ga Nihon no Kikai Buhin Boueki ni Ataeta Eikyo ni tuite), in Japanese, Master's dissertation, Faculty of Economics, Keio University, Japan.

\section{Appendix 1: New entry}

This section involves the entry of new country-products. Table 1 shows the definition of a new entry: a country-product with zero exports as of September 2008 that begins exporting between October 2008 and October 2009.

Appendix Table 3 shows the number of new-entry country-products in the machinery sector. Unlike the cases of re-entry and exit (Table 2), the number for $\mathrm{P} \& \mathrm{C}$ is smaller than for final products. As is the case for exit and entry, Asia has a large number of exports, but the number of $\mathrm{P} \& \mathrm{C}$ exports in Asia is smaller than in all other regions, while the number of final product exports is larger than in other regions. This indicates that the $\mathrm{P} \& \mathrm{C}$ trade in Asia is able to maintain long-run relationships, which thereby inhibits new entries.

Next, we turn our attention to the exit-entry diagram in Appendix Figure 1. The notable difference from the exit-re-entry diagram in Figures 3 is that it takes into account new entries. Here, entry is the number of re-entries plus the number of new-entries. Many country- 
products are now on or above the 45-degree line. This indicates that for some products the number of destinations increased after the crisis through new-entry. In particular, $\mathrm{P} \& \mathrm{C}$ are more likely to locate above final products. Thus, we can say that $\mathrm{P} \& \mathrm{C}$ trade increases after the crisis. Finally, Appendix Table 4 shows the results of the survival analysis. The results are fairly similar to the re-entry case (Table 5) in terms of the signs of the estimates. However, many estimates of the coefficients such as Asian P\&C and Asia are smaller in the new-entry case. From these results, we find some evidence of new-entry during the crisis but Asian $\mathrm{P} \& \mathrm{C}$ do not increase substantially. Once again, we can therefore conclude that Asian P\&C trade is able to maintain long-run relationships and thus new-entry is not accommodated. 
Table 1: Definitions of Terminology

\begin{tabular}{|c|c|c|c|c|c|c|c|c|c|c|c|c|c|c|}
\hline Period & to & & & 2008 Sep & 2008 Oct & Nov & & & & & & & & Oct \\
\hline Stay & + & + & $\cdot \cdot \cdot$ & + & + & + & + & + & + & + & + & + & + & + \\
\hline Exit & + & + & $\cdot \cdot \cdot$ & + & + & + & 0 & 0 & $\cdot \cdot$ & $\cdot \cdot$ & 0 & 0 & 0 & 0 \\
\hline Re-entry & + & + & $\cdot \cdot \cdot$ & + & + & + & 0 & 0 & 0 & + & + & + & + & + \\
\hline New Entry & 0 & 0 & & 0 & 0 & 0 & + & + & + & + & + & + & + & + \\
\hline
\end{tabular}

Note: This definition is country-product pair base.

"+" denotes a positive value of exports.

"0" denotes no exports

"tO" is defined as the first month to start exporting, continued until September 2008 
Table 2: Number of exit and re-entry in Machinery Sectors

Total

\begin{tabular}{|l|r|r|r|}
\hline & P\&C & Final & Total \\
\hline All products & 13760 & 11788 & 25548 \\
Exit & 5411 & 6741 & 12152 \\
Re-entry & 3515 & 4023 & 7538 \\
\hline
\end{tabular}

Note: "All products" are traded products as of September 2008

"Exit" is the product that stops exporting after October 2008. "Re-entry" is the product that restarts exporting after exit.

\begin{tabular}{|c|c|c|c|c|c|c|c|c|c|c|}
\hline & & Asia & Middle East & East Europe & West Europe & North America & Latin America & Africa & Oceania & Total \\
\hline \multirow[t]{3}{*}{ All Machinery } & All products & 9051 & 1970 & 1536 & 5888 & 1431 & 2951 & 1602 & 1119 & 25548 \\
\hline & Exit & 3264 & 1104 & 1024 & 2869 & 414 & 1824 & 1061 & 592 & 12152 \\
\hline & Re-entry & 2252 & 658 & 564 & 1792 & 254 & 1056 & 588 & 374 & 7538 \\
\hline \multirow[t]{3}{*}{ P\&C } & All P\&C & 4744 & 1054 & 865 & 3352 & 731 & 1662 & 818 & 534 & 13760 \\
\hline & Exit & 1218 & 484 & 513 & 1397 & 133 & 878 & 540 & 248 & 5411 \\
\hline & Re-entry & 837 & 324 & 305 & 935 & 92 & 542 & 323 & 157 & 3515 \\
\hline \multirow[t]{3}{*}{ Final } & All Final products & 4307 & 916 & 671 & 2536 & 700 & 1289 & 784 & 585 & 11788 \\
\hline & Exit & 2046 & 620 & 511 & 1472 & 281 & 946 & 521 & 344 & 6741 \\
\hline & Re-entry & 1415 & 334 & 259 & 857 & 162 & 514 & 265 & 217 & 4023 \\
\hline
\end{tabular}


Table 3: Probability of Exit and Re-entry by Age in Machinery Sectors $P \& C$ and Final

\begin{tabular}{|l|lrl|lr|}
\hline Total & Exit & \multicolumn{3}{|l|}{ Re-entry } \\
& P\&C & \multicolumn{2}{|c|}{ Final } & P\&C & \multicolumn{2}{l|}{ Final } \\
\hline All & 0.393 & 0.572 & 0.650 & 0.597 \\
\hline $1-6$ months & 0.936 & 0.951 & 0.525 & 0.469 \\
$6-12$ months & 0.803 & 0.793 & 0.691 & 0.643 \\
$1-2$ years & 0.501 & 0.688 & 0.758 & 0.695 \\
$2-3$ years & 0.499 & 0.553 & 0.838 & 0.778 \\
more than 3 years & 0.105 & 0.212 & 0.821 & 0.780 \\
\hline
\end{tabular}

Note: "Age" is defined as the number of consecutively traded months before exit.

\begin{tabular}{|c|c|c|c|c|c|c|c|c|c|}
\hline & & Asia & Middle East & East Europe & West Europe & North America & Latin America & Africa & Oceania \\
\hline \multirow[t]{6}{*}{ Exit } & & 0.361 & 0.560 & 0.667 & 0.487 & 0.289 & 0.618 & 0.662 & 0.529 \\
\hline & $1-6$ months & 0.923 & 0.932 & 0.980 & 0.944 & 0.948 & 0.970 & 0.938 & 0.947 \\
\hline & $6-12$ months & 0.768 & 0.781 & 0.861 & 0.773 & 0.694 & 0.855 & 0.848 & 0.797 \\
\hline & $1-2$ years & 0.496 & 0.629 & 0.647 & 0.639 & 0.554 & 0.649 & 0.701 & 0.618 \\
\hline & $2-3$ years & 0.471 & 0.444 & 0.655 & 0.585 & 0.487 & 0.561 & 0.554 & 0.474 \\
\hline & more than 3 years & 0.101 & 0.166 & 0.230 & 0.189 & 0.097 & 0.216 & 0.190 & 0.172 \\
\hline \multirow[t]{6}{*}{ Re-entry } & & 0.690 & 0.596 & 0.551 & 0.625 & 0.614 & 0.579 & 0.554 & 0.632 \\
\hline & $1-6$ months & 0.549 & 0.474 & 0.417 & 0.522 & 0.564 & 0.442 & 0.456 & 0.477 \\
\hline & $6-12$ months & 0.734 & 0.689 & 0.559 & 0.649 & 0.574 & 0.619 & 0.604 & 0.791 \\
\hline & $1-2$ years & 0.805 & 0.672 & 0.667 & 0.667 & 0.597 & 0.751 & 0.713 & 0.730 \\
\hline & $2-3$ years & 0.864 & 0.791 & 0.756 & 0.782 & 0.684 & 0.802 & 0.804 & 0.778 \\
\hline & more than 3 years & 0.832 & 0.851 & 0.857 & 0.758 & 0.722 & 0.806 & 0.709 & 0.860 \\
\hline
\end{tabular}

Region by $\mathrm{P} \& \mathrm{C}$ and Final

\begin{tabular}{|c|c|c|c|c|c|c|c|c|c|}
\hline P\&C & & Asia & Middle East & East Europe & West Europe & North America & Latin America & Africa & Oceania \\
\hline \multirow[t]{6}{*}{ Exit } & & 0.257 & 0.459 & 0.593 & 0.417 & 0.182 & 0.528 & 0.660 & 0.464 \\
\hline & $1-6$ months & 0.915 & 0.930 & 0.984 & 0.931 & 0.907 & 0.958 & 0.918 & 0.951 \\
\hline & $6-12$ months & 0.796 & 0.761 & 0.824 & 0.791 & 0.656 & 0.837 & 0.848 & 0.797 \\
\hline & $1-2$ years & 0.385 & 0.549 & 0.516 & 0.579 & 0.419 & 0.575 & 0.705 & 0.561 \\
\hline & 2-3 years & 0.446 & 0.298 & 0.638 & 0.551 & 0.500 & 0.532 & 0.647 & 0.538 \\
\hline & more than 3 years & 0.065 & 0.096 & 0.167 & 0.153 & 0.054 & 0.155 & 0.158 & 0.102 \\
\hline \multirow[t]{6}{*}{ Re-entry } & & 0.687 & 0.669 & 0.595 & 0.669 & 0.692 & 0.617 & 0.598 & 0.633 \\
\hline & $1-6$ months & 0.522 & 0.562 & 0.502 & 0.558 & 0.694 & 0.484 & 0.502 & 0.489 \\
\hline & $6-12$ months & 0.725 & 0.744 & 0.574 & 0.722 & 0.524 & 0.682 & 0.615 & 0.851 \\
\hline & $1-2$ years & 0.824 & 0.758 & 0.625 & 0.710 & 0.692 & 0.776 & 0.806 & 0.783 \\
\hline & 2-3 years & 0.908 & 0.960 & 0.886 & 0.750 & 0.667 & 0.800 & 0.955 & 0.643 \\
\hline & more than 3 years & 0.823 & 0.886 & 0.813 & 0.808 & 0.806 & 0.839 & 0.778 & 0.852 \\
\hline Final & & Asia & Middle East & East Europe & West Europe & North America & Latin America & Africa & Oceania \\
\hline \multirow[t]{6}{*}{ Exit } & & 0.475 & 0.677 & 0.762 & 0.580 & 0.401 & 0.734 & 0.665 & 0.588 \\
\hline & $1-6$ months & 0.928 & 0.933 & 0.976 & 0.955 & 0.966 & 0.981 & 0.959 & 0.944 \\
\hline & $6-12$ months & 0.755 & 0.799 & 0.906 & 0.757 & 0.712 & 0.870 & 0.848 & 0.797 \\
\hline & $1-2$ years & 0.625 & 0.720 & 0.819 & 0.711 & 0.695 & 0.750 & 0.698 & 0.656 \\
\hline & $2-3$ years & 0.490 & 0.627 & 0.680 & 0.626 & 0.481 & 0.589 & 0.507 & 0.419 \\
\hline & more than 3 years & 0.157 & 0.285 & 0.339 & 0.252 & 0.153 & 0.342 & 0.222 & 0.251 \\
\hline \multirow[t]{6}{*}{ Re-entry } & & 0.692 & 0.539 & 0.507 & 0.582 & 0.577 & 0.543 & 0.509 & 0.631 \\
\hline & $1-6$ months & 0.565 & 0.401 & 0.332 & 0.490 & 0.509 & 0.402 & 0.408 & 0.467 \\
\hline & $6-12$ months & 0.738 & 0.645 & 0.542 & 0.582 & 0.596 & 0.570 & 0.589 & 0.746 \\
\hline & $1-2$ years & 0.792 & 0.597 & 0.701 & 0.624 & 0.537 & 0.725 & 0.617 & 0.700 \\
\hline & 2-3 years & 0.833 & 0.690 & 0.588 & 0.816 & 0.692 & 0.804 & 0.706 & 0.923 \\
\hline & more than 3 years & 0.837 & 0.831 & 0.895 & 0.705 & 0.682 & 0.775 & 0.660 & 0.864 \\
\hline
\end{tabular}


Table 4: Exit Results

\begin{tabular}{|c|c|c|c|c|}
\hline & 1 & 2 & 3 & 4 \\
\hline \multirow[t]{2}{*}{$\overline{P \& C}$} & -0.2273 & & & \\
\hline & {$[-6.07] * * *$} & & & \\
\hline \multirow[t]{2}{*}{ Asia } & & -0.1514 & -0.3225 & -0.4160 \\
\hline & & {$[-2.25]^{* *}$} & {$[-3.29]^{* * *}$} & {$[-5.06]^{* * *}$} \\
\hline \multirow[t]{2}{*}{ AsiaP\&C } & -0.3665 & -0.4799 & & \\
\hline & {$[-5.36]^{* * *}$} & {$[-7.10]^{* * *}$} & & \\
\hline \multirow[t]{2}{*}{ GDP } & -0.0379 & -0.0405 & -0.0587 & -0.0503 \\
\hline & {$[-4.18]^{* * *}$} & {$[-4.43]^{* * *}$} & {$[-4.00]^{* * *}$} & {$[-4.19]^{* * *}$} \\
\hline \multirow[t]{2}{*}{ Dist } & 0.2574 & 0.1001 & 0.2293 & 0.0428 \\
\hline & {$[7.40]^{* * *}$} & {$[2.00]^{* *}$} & {$[2.89]^{* * *}$} & {$[0.66]$} \\
\hline \multirow[t]{2}{*}{ Age } & -0.0459 & -0.0462 & -0.0514 & -0.0399 \\
\hline & {$[-59.01]^{* * *}$} & {$[-59.56]^{* * *}$} & {$[-43.62]^{* * *}$} & {$[-38.71]^{* * *}$} \\
\hline \multirow[t]{2}{*}{ Unitprice } & 0.0280 & 0.0407 & 0.0959 & -0.0148 \\
\hline & {$[4.17]^{* * *}$} & {$[6.33]^{* * *}$} & {$[8.18]^{* * *}$} & {$[-1.74]^{*}$} \\
\hline $\bar{N}$ & 127850 & 127850 & 77762 & 50088 \\
\hline chi2 & 5007.23 & 4975.29 & 2866.03 & 1937.72 \\
\hline$p$ & 0 & 0 & 0 & 0 \\
\hline Sample & All & All & $P \& C$ & Final \\
\hline
\end{tabular}

Note: monthly dummies are omitted due to space limit.

The values in parenthesis are $z$-values.

$* * *$ denotes $1 \%$ significance

** denotes $5 \%$ significance.

* denotes $10 \%$ significance. 
Table 5: Re-entry results

\begin{tabular}{|c|c|c|c|c|}
\hline & 1 & 2 & 3 & 4 \\
\hline \multirow[t]{2}{*}{$P \& C$} & 0.1466 & & & \\
\hline & {$[5.74]^{* * *}$} & & & \\
\hline \multirow[t]{2}{*}{ Asia } & & 0.1950 & 0.3575 & 0.1986 \\
\hline & & {$[4.17]^{* * *}$} & {$[5.26] * * *$} & {$[3.54] * * *$} \\
\hline \multirow[t]{2}{*}{ AsiaP\&C } & 0.0987 & 0.1337 & & \\
\hline & {$[1.94]^{*}$} & {$[2.67]^{* * *}$} & & \\
\hline \multirow[t]{2}{*}{ GDP } & 0.1121 & 0.1112 & 0.1158 & 0.1170 \\
\hline & {$[18.05]^{* * *}$} & {$[17.82]^{* * *}$} & {$[12.08] * * *$} & {$[14.04] * * *$} \\
\hline \multirow[t]{2}{*}{ Dist } & -0.1775 & -0.0408 & 0.0960 & -0.1334 \\
\hline & {$[-6.96]^{* * *}$} & {$[-1.17]$} & {$[1.74] *$} & {$[-2.95] * * *$} \\
\hline \multirow[t]{2}{*}{ Age } & 0.0219 & 0.0221 & 0.0205 & 0.0224 \\
\hline & {$[25.29]^{* * *}$} & {$[25.48]^{* * *}$} & {$[15.18]^{* * *}$} & {$[19.62]^{* * *}$} \\
\hline \multirow[t]{2}{*}{ Unitprice } & 0.0043 & 0.0029 & -0.0248 & 0.0212 \\
\hline & {$[0.89]$} & {$[0.61]$} & {$[-2.98] * * *$} & {$[3.56] * * *$} \\
\hline$N$ & 97226 & 97226 & 41558 & 55668 \\
\hline chi2 & 2949.8901 & 2923.0161 & 1316.0688 & 1724.1901 \\
\hline$p$ & 0 & 0 & 0 & 0 \\
\hline Sample & All & All & $P \& C$ & Final \\
\hline
\end{tabular}

Note: monthly dummies are omitted due to space limit.

The values in parenthesis are z-values.

$* * *$ denotes $1 \%$ significance

** denotes $5 \%$ significance.

* denotes $10 \%$ significance. 


\section{Figure 1: Japan's total exports}

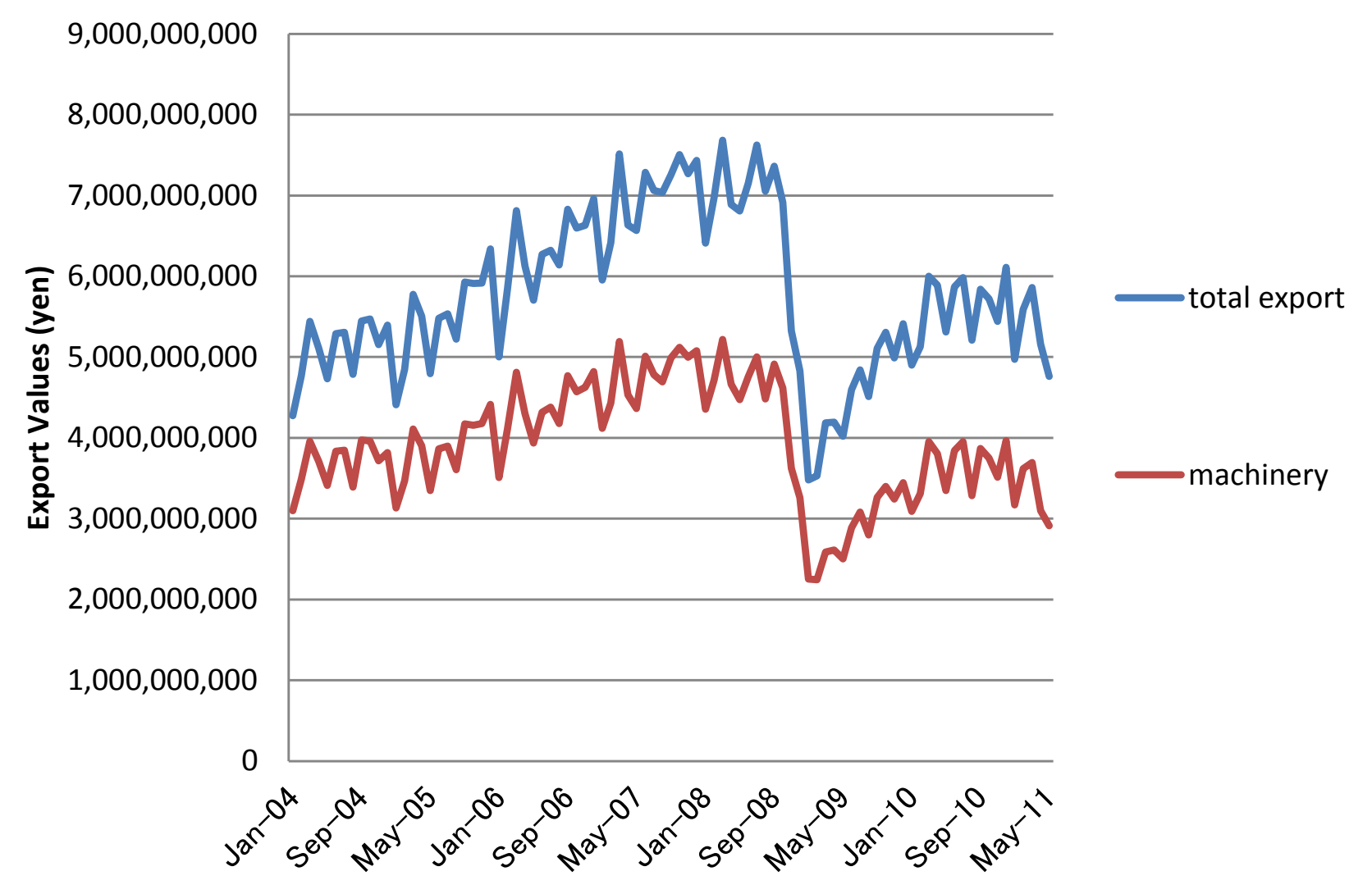


Figure 2: Number of Country-product

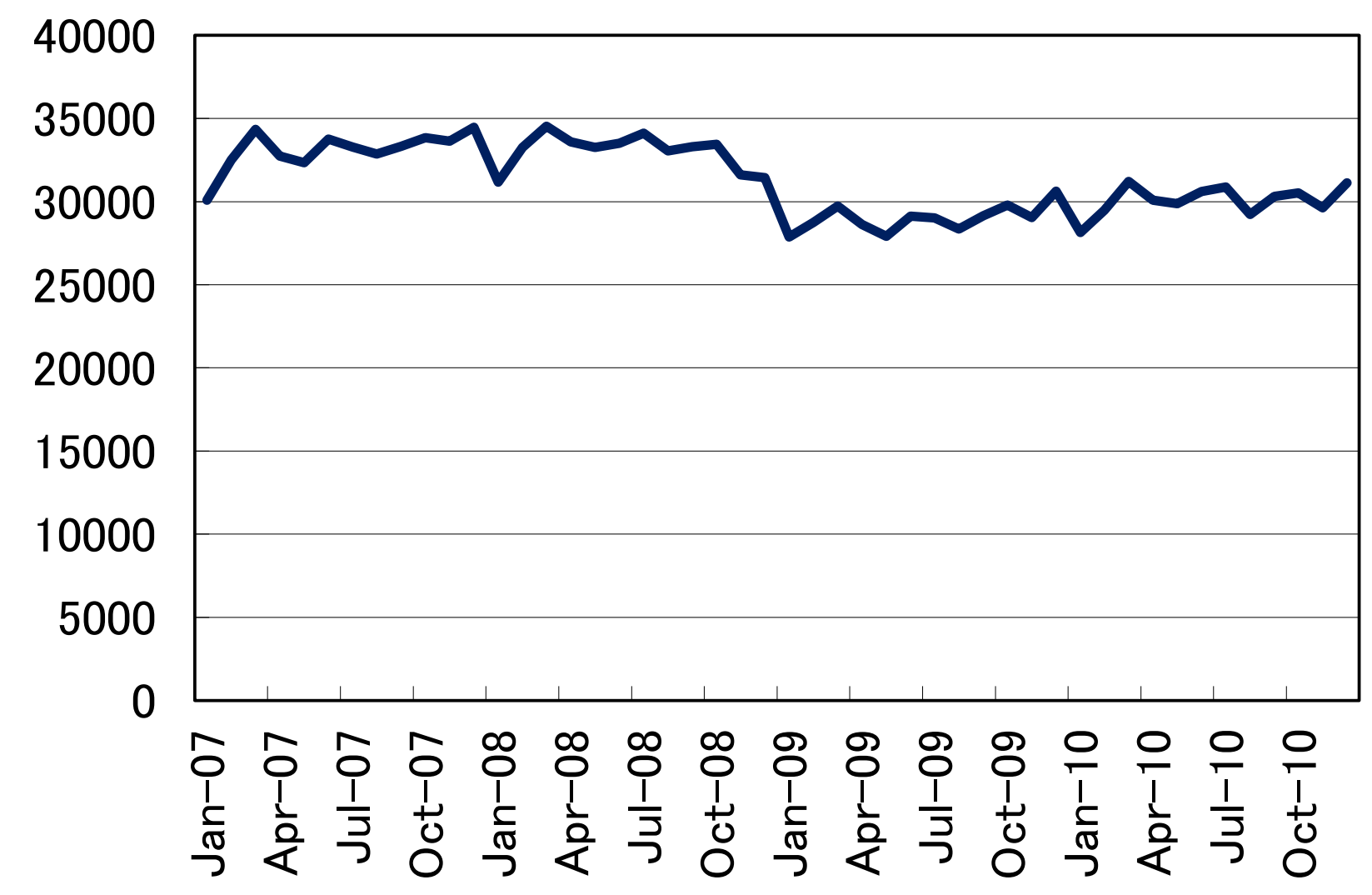


Figure 3-1 Exit=re-entry Diagram

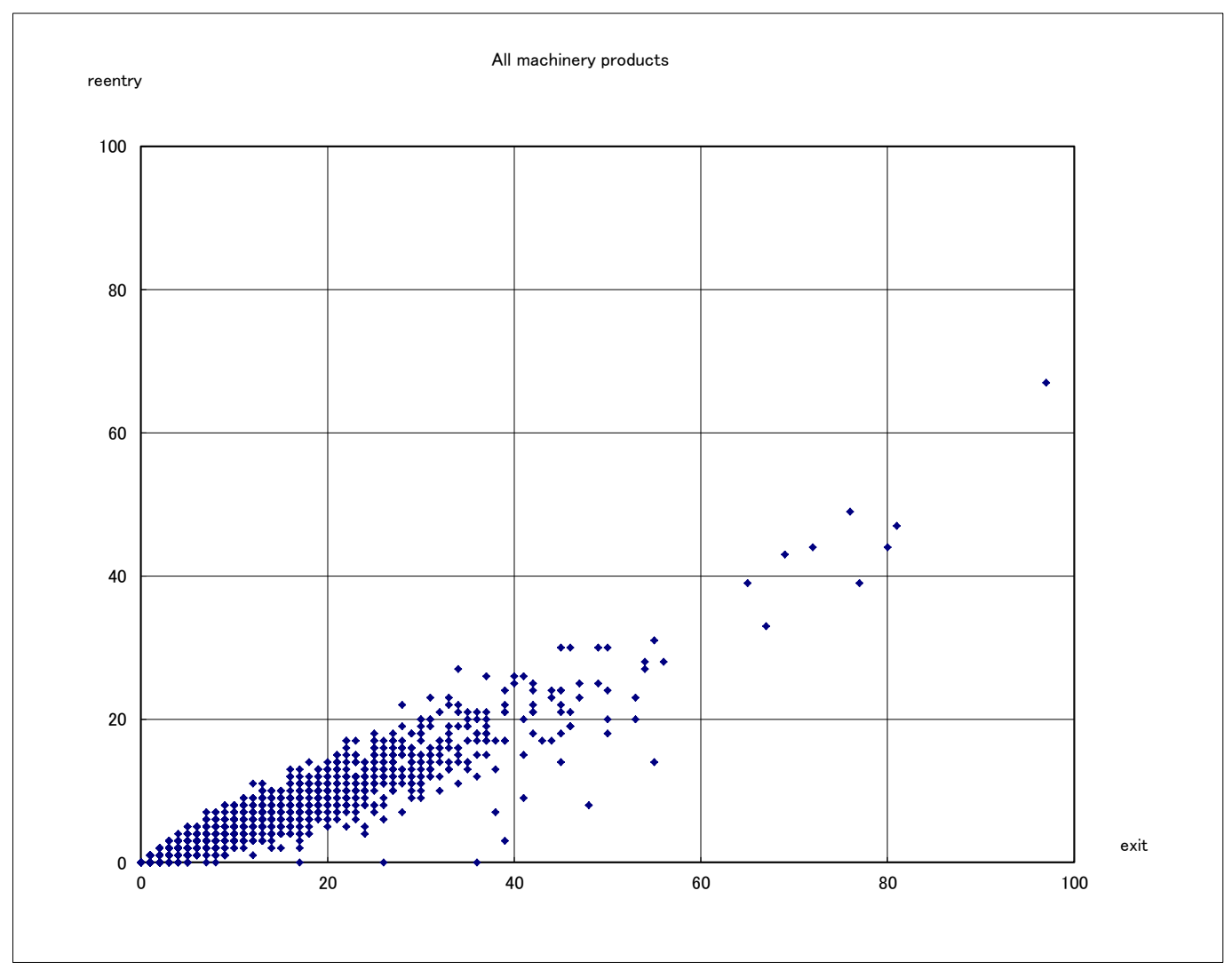

Note that every dot is one machinery product and the numbers of axes are destinations. 
Figure 3-2: Sectoral dimension

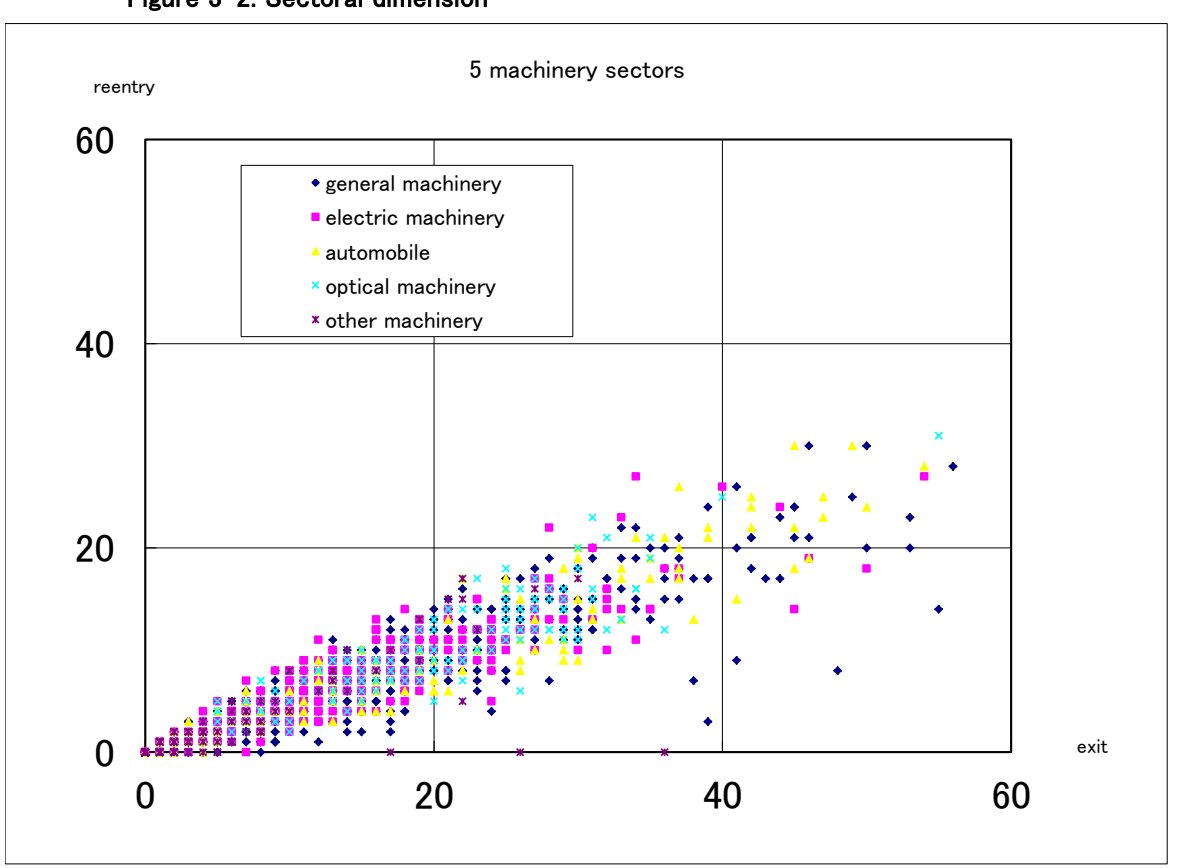

Figure 3-3 P\&C and Final Products

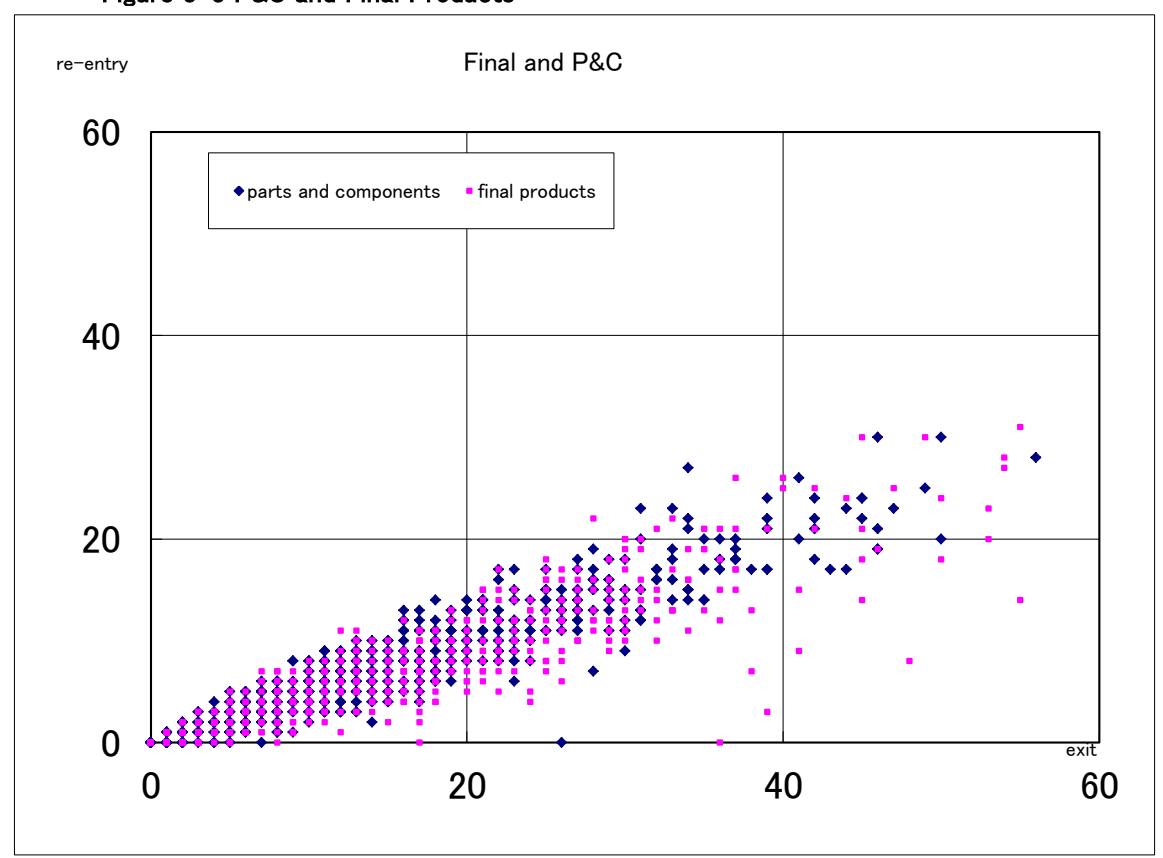

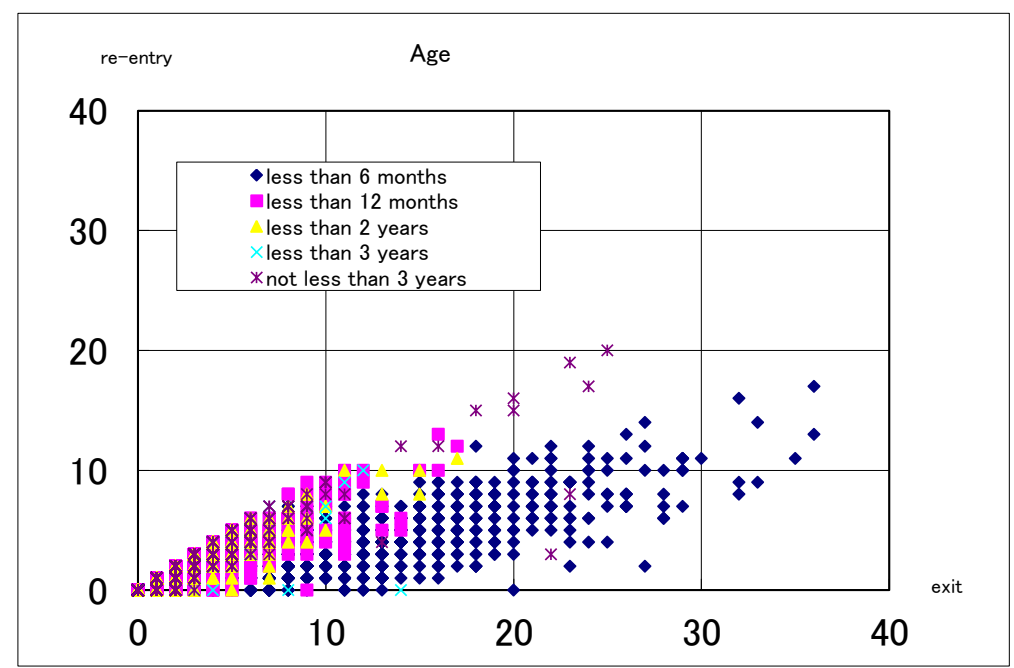

Figure 3-4 Duration of transaction (age)

Note: each dot indicates product disaggregated by age catogory 
Figure 4: Exit

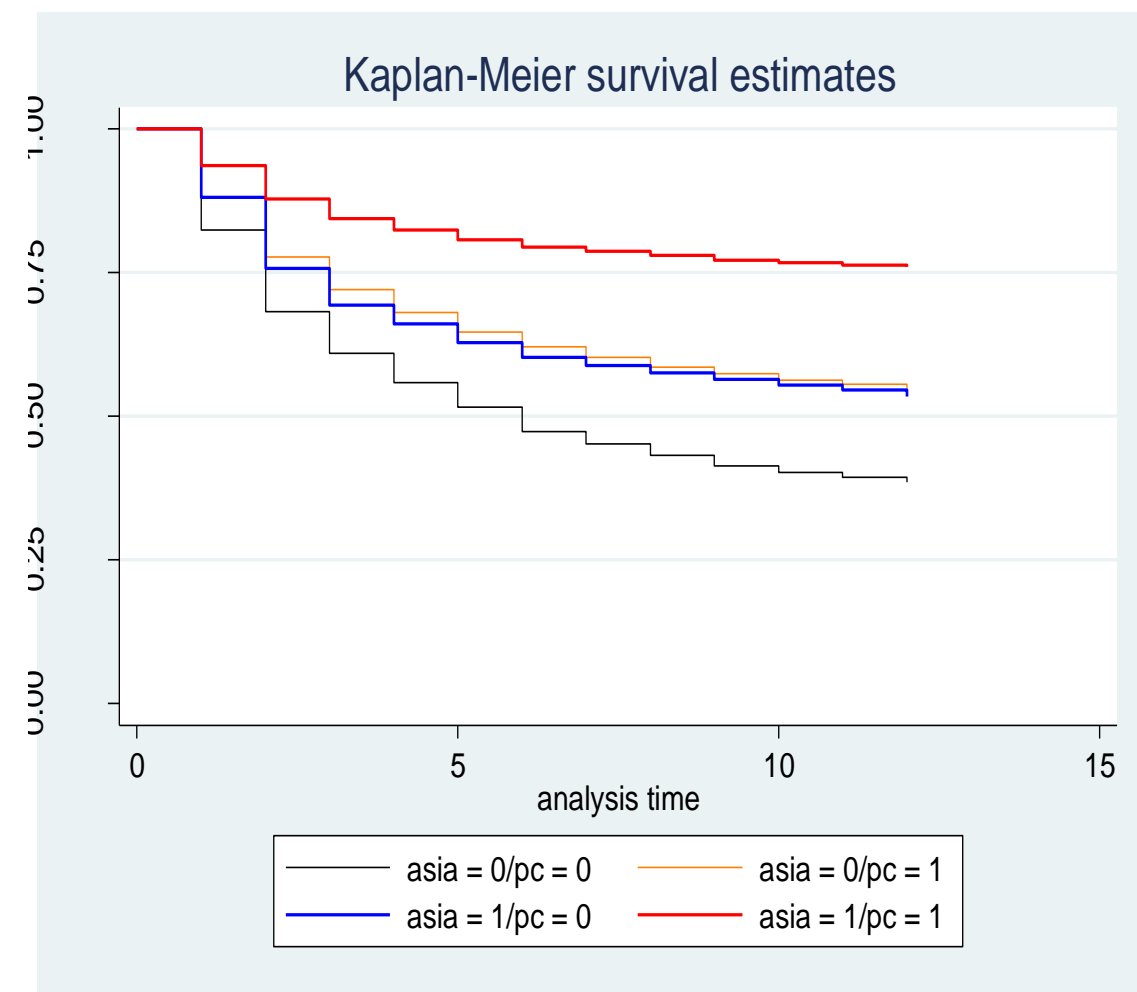

Note: time 0 is October 2008

asia: Asian dummy (Non-Asian trade $=0$,Asian Trade $=1$ )

pc: $P \& C$ dummy (Final product trade $=0, P \& C$ trade $=1$ )
Figure 5: Re-entry

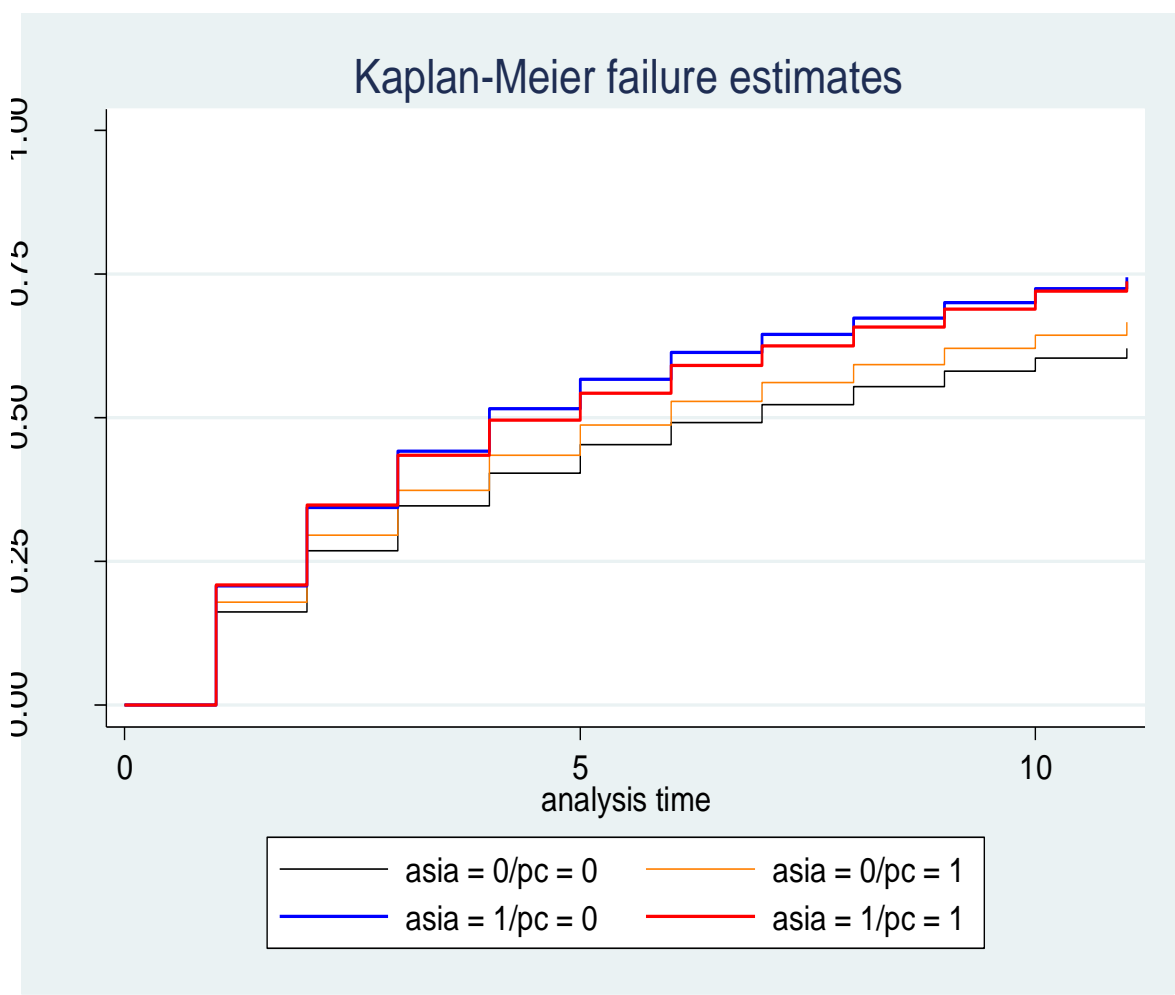

Note: time 0 is November 2008

asia: Asian dummy (Non-Asian trade=0,Asian Trade=1)

pc: $P \& C$ dummy (Final product trade $=0, P \& C$ trade $=1$ ) 


\section{Appendix Table 1: Basic Statistics}

\begin{tabular}{lcrrrrrr} 
Exit & \multicolumn{2}{c}{ Mean } & Std. Dev. & Min & Max & \multicolumn{2}{c}{ Median } \\
\hline Asian P\&C & 2132049 & 0.185 & 0.388 & 0 & 1 & 0 \\
P\&C & 2132049 & 0.549 & 0.498 & 0 & 1 & 1 \\
Asia & 2132148 & 0.351 & 0.477 & 0 & 1 & 0 \\
GDP & 1849081 & 26.568 & 1.770 & 16.905 & 30.312 & 26.450 \\
Dist & 1878257 & 8.858 & 0.624 & 7.053 & 9.830 & 9.071 \\
Unitprice & 2127909 & 2.203 & 2.401 & -7.810 & 12.998 & 1.914 \\
Age & 1792454 & 46.230 & 17.360 & 1 & 58 & 58 \\
\hline
\end{tabular}

\begin{tabular}{lrrrrrr} 
Re-entry & \multicolumn{2}{c}{ Mean } & Std. Dev. & Min & Max & \multicolumn{2}{c}{ Median } \\
\hline Asian P\&C & 120839 & 0.075 & 0.263 & 0 & 1 & 0 \\
P\&C & 120839 & 0.437 & 0.496 & 0 & 1 & 0 \\
Asia & 120839 & 0.206 & 0.404 & 0 & 1 & 0 \\
GDP & 117755 & 25.671 & 1.964 & 17.078 & 30.291 & 25.965 \\
Dist & 119843 & 9.043 & 0.502 & 7.053 & 9.830 & 9.124 \\
Unitprice & 120199 & 2.477 & 2.395 & -7.810 & 12.998 & 2.224 \\
Age & 67513 & 5.182 & 11.286 & 1 & 58 & 1 \\
\hline
\end{tabular}




\begin{tabular}{l|rrrrrrr}
\multicolumn{7}{c}{ Appendix Table 2: Correlation Matrix } \\
& Exit & AsiaP\&C & Asia & GDP & Dist & Unitprice & Age \\
\hline P\&C & 1 & & & & & & \\
AsiaP\&C & 0.4315 & 1 & & & & & \\
Asia & 0.6472 & -0.0333 & 1 & & & \\
GDP & -0.0331 & 0.0227 & -0.0557 & 1 & & \\
Dist & -0.5139 & 0.042 & -0.8156 & -0.0822 & 1 & 1 \\
Unitprice & -0.147 & -0.2627 & -0.1376 & -0.1088 & 0.1171 & 1 \\
Age & 0.1265 & 0.1069 & 0.0995 & 0.1677 & -0.1145 & -0.0471 & 1
\end{tabular}

\begin{tabular}{|c|c|c|c|c|c|c|c|}
\hline Reentry & P\&C & Asian P\&C & Asia & GDP & Dist & Unitprice & Age \\
\hline $\mathrm{P \& C}$ & 1 & & & & & & \\
\hline Asian P\&C & 0.3226 & 1 & & & & & \\
\hline Asia & -0.0759 & 0.5581 & 1 & & & & \\
\hline GDP & -0.0705 & -0.0058 & 0.0539 & 1 & & & \\
\hline Dist & 0.0764 & -0.4086 & -0.7619 & -0.0907 & 1 & . & \\
\hline Unitprice & -0.1117 & -0.052 & -0.0956 & -0.0721 & 0.085 & 1 & \\
\hline Age & -0.0054 & 0.0356 & 0.0426 & 0.1752 & -0.0623 & 0.0398 & \\
\hline
\end{tabular}


Appendix Table 3: New-entry in Machinery Sectors

\begin{tabular}{|l|r|r|}
\hline P\&C & Final & Total \\
\hline 17022 & 21075 & 38097 \\
\hline
\end{tabular}

\begin{tabular}{|c|r|r|r|r|r|r|r|r|}
\hline & \multicolumn{1}{|l|}{ asia } & middle eas & central and western e & north amer & Latin amer & africa & \multicolumn{1}{l|}{ oceania } \\
\hline Total & 7435 & 4211 & 3829 & 7119 & 660 & 6189 & 6324 & 2330 \\
\hline P\&C & 2608 & 1923 & 1808 & 3313 & 239 & 2971 & 3059 & 1101 \\
\hline Final Product & 4827 & 2288 & 2021 & 3806 & 421 & 3218 & 3265 & 1229 \\
\hline
\end{tabular}


Appendix Table 4: Results of New-Entry

\begin{tabular}{|c|c|c|c|c|}
\hline & 1 & 2 & 3 & 4 \\
\hline \multirow[t]{2}{*}{$P \& C$} & 0.0588 & & & \\
\hline & {$[5.38]^{* * *}$} & & & \\
\hline \multirow[t]{2}{*}{ Asia } & & 0.1033 & 0.1234 & 0.1086 \\
\hline & & {$[4.90]^{* * *}$} & {$[4.06]^{* * *}$} & {$[4.31]^{* * *}$} \\
\hline \multirow[t]{2}{*}{ AsiaP\&C } & 0.0402 & 0.0338 & & \\
\hline & {$[1.69]^{*}$} & [1.38] & & \\
\hline \multirow[t]{2}{*}{ GDP } & 0.0905 & 0.0900 & 0.0992 & 0.0889 \\
\hline & {$[35.95]^{* * *}$} & {$[35.66]^{* * *}$} & {$[26.20]^{* * *}$} & {$[26.42]^{* * *}$} \\
\hline \multirow[t]{2}{*}{ Dist } & -0.0935 & -0.0269 & 0.0135 & -0.0625 \\
\hline & {$[-7.69]^{* * *}$} & {$[-1.65]^{*}$} & [0.53] & {$[-2.92]^{* * *}$} \\
\hline \multirow[t]{2}{*}{ unitprice } & 0.0167 & 0.0136 & -0.0213 & 0.0057 \\
\hline & {$[5.26]^{* * *}$} & {$[4.33]^{* * *}$} & {$[-5.59]^{* * *}$} & {$[2.19]^{* *}$} \\
\hline $\bar{N}$ & 242095 & 242095 & 107180 & 132982 \\
\hline chi2 & 3081.533 & 3076.515 & 1437.4652 & 1690.366 \\
\hline$p$ & 0 & 0 & 0 & 0 \\
\hline$\overline{\text { Sample }}$ & All & All & $P \& C$ & Final \\
\hline
\end{tabular}


Appendix Figure 1: Exit=Entry Diagram
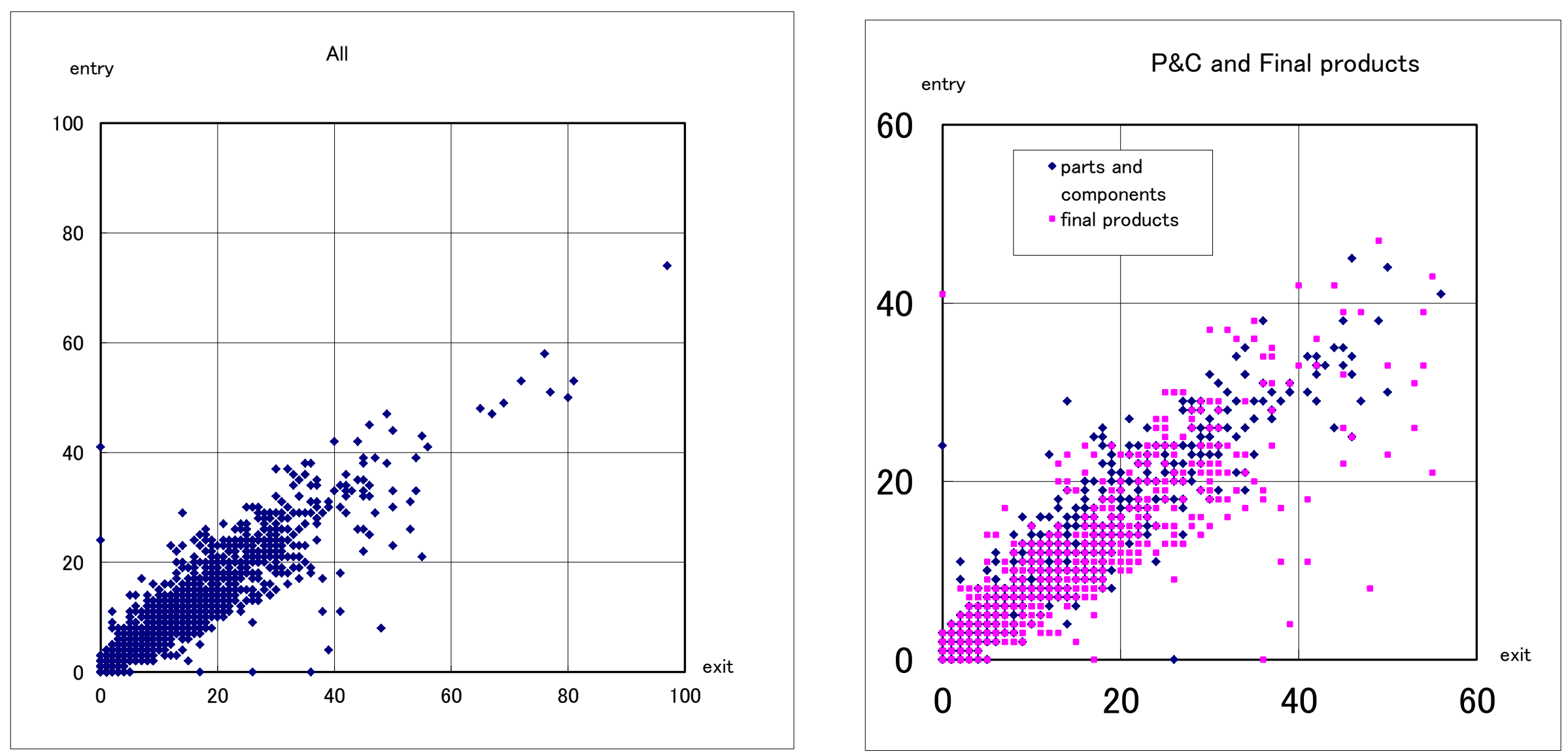